\title{
THE INVOLVEMENT OF JAPANESE MNES IN THE INDONESIAN AUTOMOTIVE CLUSTER
}

\section{DESSY IRAWATI}

Newcastle University - Business School

$1^{\text {st }}$ Floor-Citywall-Citygate, Newcastle upon Tyne, NE1 4JH

UNITED KINGDOM

E-mail: d.irawati@ncl.ac.uk

\section{DAVID CHARLES}

Curtin Business School - Curtin University of Technology

GPO Box U1987, Perth, Western Australia 6845

AUSTRALIA

E-mail: david.charles@curtin.edu.au

\begin{abstract}
The Indonesian government has applied a form of cluster policy in the automotive sector drawing upon multinational enterprises (MNEs) to develop the dynamic capabilities of the industry. Cluster policies are seen by government as a way to enhance competencies within the automotive cluster in Indonesia, particularly the work organization for flexible production systems and skills, as well as building up the global-local production networks.

Case studies of Toyota and Honda in Indonesia examine the international transfer of technology seen through the perspective of work organization, in order to assess whether sophisticated Japanese production management technology has been successfully transplanted into Indonesia. These case studies investigate whether there is a successful catching-up process, where MNEs (Multinational Enterprises) through top-down knowledge transfer, are able to advance Indonesian's technological capability in the automotive industry.
\end{abstract}

Keywords: Automotive Policy, MNEs, Clusters, Technology and Knowledge, Knowledge Transfer, Networks 


\section{Introduction}

The Asian financial crisis of 1997 had serious repercussions for the automotive industry in the ASEAN region (Mikler 2007). Sales declined and production was scaled back. Despite this, the Japanese dominance of the automotive industry in Southeast Asia, particularly in Indonesia, remained firm, and although the American and European makers gained some market share (Sato 2001, Busser and Sadoi 2004, Rasiah 2005, Wee 2005), the crisis deepened Japanese involvement in the ASEAN automotive sector as the Japanese MNEs made additional investments in existing joint ventures to save these endangered enterprises.

In Indonesia, the government has been trying hard to get their economy back on the right track after being devastated by the economic crisis (MOSR 2002, MOTIRI 2005, Rasiah 2005). A key policy has been an open trade stance to ensure that there is a major industry rationalisation in the automotive sector (Soesastro 2003, ADB 2006, Perdana and Friawan 2007). An open foreign investment regime combined with an industrial extension programme labelled as the industrial cluster policy, and measures to promote technology transfer from foreign to local firms, were all intended to facilitate continuous improvement in supply-side capacities (Aswicahyono et al. 1999, Tarmidi 2004, Wee 2005). This cluster policy has been perceived by the automotive industry as encouraging networks between the Japanese MNEs and their global-local keiretsu. This policy had been implemented since the 1990s but in the aftermath of the financial crisis the government decided to push the private sector to be involved in developing the industrial clusters across Indonesia (MOSR 2002).

Based on case studies of Toyota and Honda, as the leading automotive players in Indonesia, this paper examines the process of cluster development and the benefits to the Indonesian automotive industry. The research particularly focuses on the importance of the Japanese keiretsu in developing the cluster, and in what way the global-local production system accelerates the cluster's development. The paper begins with a theoretical framework on clusters and FDI in developing countries. This is followed by a description of the development of the Indonesian automotive industry. The main empirical focus is the case studies of the technology and knowledge transfer process involved within Toyota and Honda. The consequences for the Indonesian automotive cluster of the globalization of the Japanese transplants is discussed with some final conclusions on how the cluster policy could be improved and what lessons can be learned.

\section{Theoretical Framework: Clusters in Developing Countries and Foreign Direct Investment (FDI)}

Clusters have grown to be an object of aspiration for many regions (i.e. BadenWürttemberg, the $3^{\text {rd }}$ Italy, Silicon Valley, Route 128-Boston, and Cambridge). Nevertheless, little is known about the critical success factors that determine the economic development of cities and regions, and empirical studies that draw lessons for policy are scarce, particularly cluster studies for developing countries in the Southeast Asian region, such as Indonesia. 
Previous research on clusters in developing countries has mainly focused on the traditional industry sectors and SMEs (Altenburg and Meyer-Stamer 1999, Bell and Albu 1999, Meyer-Stamer et al. 2001, Giuliani 2006), and has yet to highlight hi-tech industries such as the automotive sector. As a result, most of the literature on automotive clusters has been derived from the mature clusters in developed countries where the automotive presence is predominantly parent companies rather than subsidiaries (Klepper 2001, Klepper 2004, Cantner et al. 2004, Tallman et. al 2004, Boschma and Wenting 2006).

In order to attract foreign investment, many developing countries have enacted significant policy reforms in the form of first and second generations of investment promotion policies. The first generation of investment promotion policies consisted of market-friendly policies: investment regimes were liberalized by reducing barriers to inward FDI, standards of treatment for foreign investors were strengthened, and a greater role was given to market forces in resource allocation. Hanson (2001) reports that developing countries at all levels of development have created a policy infrastructure to attract multinational firms, taking measures such as expediting the approval process, removing restrictions on the repatriation of profits, strengthening their standard of property rights, providing liberal tax incentives, and allowing foreign participation in the privatization of state-owned enterprises. However, the continued capital flight from developing countries demonstrates that the private investment response to these reforms has so far been disappointing. Yet, the concept of clusters of complementary firms as a determinant of attracting FDI, while present in policy debates, has not received much attention in the economic literature. Focusing on linkages, where each investor makes their investment decision based not only on their own perception of policy reform, but also on the investment decisions of other investors, may be more useful.

In developing economies, the first systematic effort to analyse industrial clusters has followed a common approach based on the concept of collective efficiency (Schmitz, $1982,1995,2000)$ in an attempt to define a methodological approach to assess the functioning of clustered firms in such countries. This focus was stimulated by the success stories of Italian industrial districts in the 70s-80s (Piore and Sabel 1994). In developing countries, thus, clustering was thought of as a viable way to foster the development of small local (informal) industry and to eliminate the growthconstraints of small realities (Schmitz, 1982, 9): "....such clustering opens up efficiency gains which individual firms can rarely attain. The concept of collective efficiency is defined as the competitive advantage derived from local external economies and joint action" (Schmitz H., 1995: 530). In this approach, geographical and sectoral concentration (clustering per se) does not necessarily provide any beneficial effect unless an active process of inter-firm co-operation and constructive competition has been set up.

More recent contributions have started emphasising the role of external sources of knowledge in rejuvenating local knowledge flows and on this point there is growing concern about finding a theoretical approach that could link local agglomerations such as clusters of small and medium enterprises and the global economy. Typically even the resources for product and functional upgrading are seen mainly to come from within localities: links with the wider world are frequently acknowledged, but they are weakly theorised. As a consequence, the focus of analysis has shifted from local co- 
operation dynamics to local-global links and the 'Global Value Chain' approach (Gereffi et al. 2005). Different studies now, both theoretical and empirical, (Gereffi 2001, Humphrey and Schmitz 2000, Gereffi et. al 2004, Morisson and Rabellotti 2005) put emphasis on the role of global foreign buyers as the main carriers of knowledge flows towards the cluster. Buyers exert on local firms a quasi-hierarchical form of governance which is aimed at producing product and process upgrading. There is substantial evidence of increased production capabilities (in the sense given by Bell and Pavitt 1993) in local firms, that upgraded the quality and the pace of their production (thus reducing time to market and time to order) (Humphrey and Schmitz 2000).

Another way of analysing agglomerated firms in developing countries has been that of applying the National System of Innovation (NSI) approach (Lundvall 1992, Nelson 1993) to a local context (hence, 'Local Systems of Innovation' (LSI)). As such, innovation and learning are not limited to R \& D effort but learning by using, by doing and by interacting (Lundvall 1998) are emphasised. The interaction among actors in the innovative process is central in these kinds of studies, thus reinforcing the idea that localised firms enjoying different kind of links (as in clusters), might easily interact and produce changes.

Consequently, since clusters have life cycles, regions must be continually vigilant, scanning market and technological trends (Pavitt 1987, Patel and Pavitt 1998, Cooke 2001, Asheim and Isaksen 2002). It is important for successful clusters to have contingency plans for changes in consumer tastes and demand and for new technologies that might result in market shifts (Pries and Schweer 2004). The cluster, if well organised and self aware, can become the mechanism that gathers information, predicts shifts, and finds new opportunities (Breziz and Krugman 1993, Fujita et al. 1999, Fujita and Krugman 2004).

Knowing and understanding clusters is a value to regions only if that knowledge leads to actions that grow economies and raise standards of living. Unfortunately, there is no single recipe for developing countries to follow that will meet the needs of all clusters, which embody many types of systematic relationship and kinds of industries (Fujita et al. 1999, Fujita and Krugman 2004). But there is a menu of actions from which to choose. The choices developing countries make depend on many factors, including geography, stage of development, resource constraints, special societal needs, clusters priorities, market imperfections, and local preferences.

\section{Multinational Enterprises (MNEs) and Knowledge Transfer}

MNEs are major vehicles of international technology transfer as their activities cover the selection of technologies for transfer, the choice of transfer channels, and transaction pricing and contractual mechanism and negotiation (Pedersen et al. 2003). International technology transfer will involve the international participation of a business and it can be examined by following sequential stages in the life cycle of the product or process development (Kiba and Kodama 1991, Pedersen et al. 2003). New modes of transferring technology can result in profound institutional change (Asheim and Cooke 1999). Traditional institutions have transformed into new organizations characterized by their knowledge transfer/knowledge sharing platforms. This kind of 
organization can overcome various fundamental obstacles to the evolution of an effective environment for a knowledge-based economy (Amin 2002).

Theory and practice have revealed that the interaction between the different agents involved in the innovation process is important for successful innovation (Morgan 1997, Lagendijk and Charles 1999). Firms almost never innovate in isolation (DeBresson 1996). Networks of innovation are the rule rather than the exception, and most innovative activity involves multiple actors (Ernst and Kim 2002, Nooteboom 2004). To successfully innovate, companies are becoming more dependent on complementary knowledge and know-how in companies and institutions other than their own. Contrary to the heroic Schumpeterian entrepreneur, innovation is not the activity of a single company, but rather, an active search process (Yeung 2000, Coe et al. 2008). A firm's competitiveness is increasingly more dependent upon its ability to apply new knowledge and technology to products and production processes.

At the same time, the rate of specialisation is rising. Companies in the automotive industry are developing strategies to cope with their increasing dependency on their environment (Liu and Dicken 2006, Mikler 2007), for example, more flexible Japanese automotive organizational structures and the integration of various elements in the production chain through strategic alliances, joint ventures and consortia in the name of keiretsu. The division of labour between dissimilar and complementary firms is based on the strategic choice that firms have to make between internalising knowledge and sharing information with external actors. The main goal of most strategic alliances has been to gain access to new and complementary knowledge and to speed up the learning process.

\section{Indonesian Automotive Development}

The automotive industry in Indonesia has existed since 1927 when General Motors built a car plant in Jakarta, however other firms did not follow and GM remained the only car assembler. Cars and motorcycles were imported and until the 1960s the number was relatively small. Before 1969, automotive imports were not regulated and the industry consisted mainly of trading activities with very limited assembling operations (Sato 2001, Soesastro 2003). Nevertheless, assembling activities started in 1964 with semi-knocked-down components, which progressed into the assembling of knocked-down parts in 1971.

Subsequently, the Indonesian automotive industry has become more significant but generally inefficient owing to a highly distorted policy regime in the past (Aswicahyono et al.1999, Aswicahyono and Anas 2000). Nevertheless, the industry achieved some progress as indicated by growth and an increase in knowledge and technological capacities under the continued support of the Japanese automotive makers in particular (Wee 2005, Rasiah et al. 2008).

In the past, the Indonesian government often complained that the Japanese automotive makers were slow in transferring their technology to their Indonesian affiliates, specifically during the 1970s (Hill 1997, Aswicahyono et al. 1999, Tarmidi 2004, Perdana and Friawan 2007). However, the failure to make a significant contribution to 
tap into local knowledge capabilities in transferring technology was largely due to the Indonesian government's failure to have a firm policy direction. In fact, the government was indecisive and drifted between various interest of firm-owners and government officials (Tarmidi 2004).

The Indonesian government has always supported the ambition to establish a national automotive industry through import substitution. Therefore, to increase the role of local manufacturing, the government stipulated a deletion programme in 1979. It was a programme to encourage the local manufacture of automotive components and aimed at increasing the local content, leading in the end to full manufacturing by 1986.

Additionally, the Japanese automotive makers in Indonesia responded positively. Faced with the time schedule of the deletion programme, most Japanese principals persuaded their subcontractors and suppliers in Japan to undertake direct investments in Indonesia. This initiative later led to the agglomeration of the automotive industry in Java region (Hill 1997, Kuncoro 2002). Furthermore, for engines and rear bodies, which require large investment, the Japanese principals themselves invested in engine and body press factories. For other functional components, such as transmission and brake systems, the government approved the establishment of only one locally owned factory, in order to secure production scale and local ownership (Sato 2001).

Nevertheless, under the pressure of global trade liberalization, the government had to abandon non-tariff trade regulations and the compulsory deletion programme in 1993 (Tarmidi 2004). As a result, manufacturers became free to choose the kind of component they wanted to produce. This policy motivated automotive makers, in particular the Japanese, to develop their own automotive products including components.

When the government banned imports of CBU cars (i.e. completely built up cars are imported fully built) in 1971 to protect the domestic automotive assembly industry, it also levied high import tariff rates on imports of CKD components (i.e. completely knocked down are all the components, and parts needed to build a complete car, brought into the country, and assembled in an assembly plant), making cars very expensive in Indonesia (MOTIRI 2005). Nevertheless, it was argued that the government has pursued the wrong policy by linking the tariff incentive system with the local content proportion level. In fact, no country has ever succeeded in developing an automotive industry by increasing the local content proportion (Aswicahyono et al. 1999, Tarmidi 2004, Rasiah 2005). On the contrary, some countries such as Spain, Belgium and Mexico have succeeded in developing their own automotive industry after they abandoned the local content requirement policy (Rasiah 2004, 2005, Rasiah et al 2008). The object is to increase the production in order to create an attractive captive market for component production, and then investors will come. A small market is not attractive for an automotive component manufacturer.

\section{From Technology Transfer to Knowledge Transfer in the Indonesian Automotive Cluster: Case Studies of Toyota and Honda}


Toyota and Honda have intensified investment in their plants in the automotive cluster in Indonesia. The key question is can the Japanese manufacturing system and its associated management techniques really contribute to the Indonesian automotive cluster? The case studies of Toyota and Honda show that the process of global local technology transfer can be done gradually, despite the constraints of Japanese secrecy and a slow pace of technology transfer particularly from the early 1980s until the late 1990s.

In line with Japanese understanding of knowledge as primarily 'tacit', most of the Japanese automakers segment tacit knowledge into two dimensions (Nonaka and Takeuchi 1995, Harada 2003, Fujimoto 2007). First is the technical dimension, which encompasses informal and craft elements in the form of know-how. Second is the cognitive dimension consisting of mental models, beliefs, 'credo', and perceptions and which is shaped by the surrounding environment. Thus, Toyota and Honda have come to realize that tacit knowledge cannot be easily communicated, as knowledge also embraces ideals, values, and emotion along with images and symbols.

In Toyota and Honda the process of knowledge transfer started from technical capability, involving transferring knowledge through people by on-the-job training (OJT). For this reason, OJT has been considered Japan's 'inner mechanism of technology transfer' (TMI 2007a, TMI 2007b, Honda 2007). OJT not only provides technical and administrative knowledge to the employees, but also coaches them how to have higher motivation and better discipline so that the process of never-ending quality improvement (i.e. kaizen) can be fulfilled. Unlike European and American companies, which utilize written manuals and detailed job description (Dyer and Nobeoka 2000, Harada 2003), the Japanese firms support their production management methods and their technical training through OJT.

To comprehend the nature of Japanese FDI it is necessary to distinguish the form of their FDI and knowledge diffusion in the beginning of their globalization engagement. FDI in Japanese automotive MNEs may be classified into two kinds, namely developing country-oriented FDI and developed country-oriented FDI. This classification is based on the Japanese FDI destination as an appropriate approach to explaining both the traditional global strategy of Japanese MNEs and the recent shift in the pattern of Japanese automotive FDI all over the world (Dicken and Henderson 2003, Fujimoto 2007). For a substantial period, the Japanese economy has depended for its maintenance and growth upon external trade with foreign countries; hence, it has been an export-oriented economy. During the process, the necessity to utilize cheap labour and natural resources in neighbouring countries has been widely recognized. As a result, they have been able to establish a well-formed network of production alliances that include Indonesia.

In contrast, FDI in developed countries, such as the US and European countries, had been considered initially only as access to markets for completed products rather than as either the provision of resources or the sites for production plants (Dicken and Henderson 2003, Fujimoto 2007). This connotes a sharp distinction between the production and marketing functions in Japanese industry; hence, production was centred in Japan and in the neighbouring Asian countries whereas marketing was focused in the developed European countries and the US. Moreover, Japanese companies in developed countries are placed at a relative disadvantage in securing 
low cost labour and materials. Hence, the Japanese subsidiaries in developed countries tend to equip themselves with higher technology than is the case of those in developing countries.

Nevertheless, the arguments about 'the beginning of Japanese FDIs', particularly in developing countries in the ASEAN ${ }^{1}-4$ has changed (Ozawa 2005, ADB 2006). In other words, in investing directly in ASEAN-4 (i.e. Indonesia, Thailand, Malaysia, the Philippines), Japanese automotive MNEs have shown a tendency to place their plant sites in lucrative market countries where their products have already dominated, particularly in Indonesia.

This changing pattern of Japanese automotive FDI in both developing countries and developed countries encompasses changes in management style, technology level, and organization structure. However, it seems to be insufficient to explain overall changes in the global strategy of Japanese automotive MNEs in the context of the dramatically changing world economy. Therefore, interpreting the empirical evidence of the recent automotive industry requires an understanding of the origins and rationale for of Japanese automotive FDI.

Since Indonesia is still treated as a developing country for Japanese technology transfer; it is difficult to measure the process. It is better to try to understand a process, which is quite complex and a long-term commitment. Consequently, technology transfer here may be seen as the method, knowledge, and skill used to improve and enhance the production and distribution of goods and services in the automotive industry. As a result, it can be embodied in different forms: the machinery used in production or distribution; the manuals detailing business procedures; or the minds of technicians, engineers, and managers who design and execute those procedures. For this reason, it might be seen that technology transfer is nothing more than the movement of such a method, knowledge, or skill from one country to another.

In view of that, for effective technology transfer to occur, it is argued that local firms as well as the human resource in the host country must be able not only to operate the imported technology, but to adapt and master it to suit local conditions. Therefore, it needs an understanding of the underlying nature of the imported technology, and thus a mastery of it, in this case transferring the automotive engineering from Toyota and Honda to their subsidiaries in the Indonesian automotive cluster. Both Japanese engineers and Indonesian engineers must adapt and incorporate the local values with the standardized TPS (Toyota Production System) and NH circle. This has been done by choosing OJT (on the job training) programme, for sharing knowledge and mastering the engineering techniques from Japan (Odaka et.al 1988). The Toyota Production System (TPS) is an integrated socio-technical system, developed by Toyota, that comprises its management philosophy and practices. The TPS organizes manufacturing and logistics for the automobile manufacturer, including interaction

\footnotetext{
${ }^{1}$ ASEAN is The Association of Southeast Asian Nations, or ASEAN, was established on 8 August 1967 in Bangkok, the Founding Fathers of ASEAN, namely Indonesia, Malaysia, Philippines, Singapore and Thailand. Since then, membership has expanded to include Brunei, Burma (Myanmar), Cambodia, Laos, and Vietnam. Its aims include the acceleration of economic growth, social progress, cultural development among its members, the protection of the peace and stability of the region, and to provide opportunities for member countries to discuss differences peacefully. http://www.aseansec.org/
} 
with suppliers and customers. The system is a major precursor of the more generic "Lean manufacturing." Taiichi Ohno, Shigeo Shingo and Eiji Toyoda developed the system between 1948 and $1975^{2}$. Honda NH circle is activities used in Honda's educational aspect is the Honda counterpart of the QC circles of many Japanese automotive companies. The NH circle system now operates in the entire Honda group as well as in the companies and workshops associated with each local factory. In the mid-eighties, $\mathrm{NH}$ circles were set up in Honda companies overseas where they have produced remarkable results.

Additionally, the nature of the technology that Japan transfers to advanced industrialized countries is fundamentally different from that of the technology transferred to Indonesia as a developing country (i.e. Toyota and Honda). The former includes patented high-level technology, while the latter is mainly modernization experience and skills closely related to standardized production methods, for instance the scope of a typical technology transfer contract usually covers production, management, and marketing (Sugiyama and Fujimoto 2000, Fujimoto 2007).

Japanese FDI in the automotive cluster in Indonesia in general is merely a smart, rational, and entrepreneurial response to changing cost conditions in Japan. Being rational, therefore, direct investment from Japan has contributed to the economic development of the automotive cluster in Indonesia, not only by promoting capital formation, production and employment, but also upgrading technological capability through technology transfer. It is all part of a chain of unintended benevolence in which Japanese production causes Japanese economic growth, which stimulates overseas production in the Indonesian cluster (and Asia in general), which triggers technology transfer, which links to local economic growth.

Not all FDI is the same however and the automotive industry differs from some other sectors such as electronics which are more cautious about the risk of spilling technology (Hatch and Yamamura 1996). Japanese companies in electronics are argued as being slower in the localization of managerial and technical personnel, slower in promoting them, and slower in training. In fact, they also appear more reluctant to set up design and R \& D units in the host countries (Biers 1994, Chia Siow Yue 1991). In the electronics industry, it is argued that due to the nature of the industry, Japanese MNEs do not want to spread their technology to firms outside their keiretsu (Ernst 1994). Japan's large, oligopolistic firms enjoy what is called relative asymmetries of access to trade and investment opportunities in their own and their partner's countries. This asymmetry created by government policy and business practices, makes Japanese knowledge relatively difficult to appropriate. Ernst (1994) argues that the closed nature of Japanese regional production networks has constrained the opportunities for host country firms to develop their own technological and organizational capabilities that are necessary for continued upgrading of their production efficiency and product mix.

In contrast, the FDI in the Indonesian automotive cluster serves as a particularly effective mode of technology transfer (Tarmidi 2004, Fujimoto 2005). Moreover, it is argued that FDI in this sector is likely to bring about a more effective transfer than

\footnotetext{
${ }^{2}$ More information is available on http://www.strategosinc.com/toyota_production.htm
} 
other channels since it involves a sustained relationship between the transferers and the transferee (Dicken and Henderson 2003). This assertion is based on the assumption that technology naturally diffuses through the training of local suppliers in the clusters, who may be expected to meet higher standards of quality control, reliability, and speed of delivery and through the training of local managers and technicians, who eventually might move from foreign to local firms, thus transferring human capital.

The domination by the Japanese automotive firms of the Indonesian automotive cluster also has triggered a growing number of local suppliers to the Japanese auto manufacturers, although they are 'still' Japanese affiliates. It is thus argued that increased local procurement does not necessarily mean increased business opportunity for domestically owned suppliers.

"In the real story, there was an overwhelming tendency from the big name Japanese car makers in Indonesia to buy parts from Japanese affiliated companies in Indonesia. The move towards procuring parts from the local has progressed only in the form of Japanese parts manufacturers establishing local production base. Therefore, we are lucky enough to have the strong ties with subcontractor plants and therefore we can be part of their keiretsu" (PT. NTRI supplier representative 25 May 2007)

Japanese automotive manufacturers simply responded by coaxing long-time suppliers in Japan to follow them into Asia. Therefore, the level of competition between localJapanese alliance firms and purely local firms is tough. The local firms in many cases have been struggling to survive in a tough market to win the supplier contracts from the Japanese car manufacturers. Purely Indonesian auto part firms have explained this as follows:

\footnotetext{
"It is like being a step-child in the Japanese auto family and it is an ongoing concern. Of course, there is fairness in the bidding process of a new car project from Japanese carmakers; however, the preference is always the priority of Indonesian-Japanese firms, not local firms like us. Therefore, we must show our best performance to compete with them; otherwise, we will not survive in this game. Another down side effect is the ability to enhance technological capability. For them, it is not a difficult case as they belong to Japanese keiretsu so that they can have training and upgrading skill as part of supplier scheme. But for us, we must be updated by ourselves alongside a limited market both in the local and internationally" (PT. Menara Terus Makmur supplier representative 20 May 2007)
}

These are difficult problems but hardly insurmountable. What truly stunts the growth of local suppliers is the fact that Japanese automotive MNEs in this region are building a tight network of dedicated suppliers from Japan, but a far looser, or wider, network of domestically owned suppliers. In other words, they are employing what some call 'market sharing agreements' and others call 'multiple sourcing' - a practice in which large assembly firms purchase the same or similar product from different suppliers at different times. 
Accordingly, as more and more Japanese subcontractors respond to home and host government incentives by investing capital or licensing technology in Asia, native suppliers seems to get a smaller share. They finally begun to complain to government officials throughout the region (Tarmidi 2004).

Protests though have not paid off. To win contracts, local suppliers often relinquish control to Japanese managers by entering into a joint venture or technical tie-up (Honda 2007, TMI 2007a, 2007b). However, try as they might, local business people cannot always convince Japanese business to seal a contract. Toyota and Honda offer a variety of reasons to explain their strong preference for Japanese transplants rather than local suppliers. For instance, local suppliers cannot or will not keep up with their delivery schedule, causing them to shut down assembly lines as they wait for shipments of needed inputs, which compromises their JIT production system. Still others complain that local suppliers, left on their own, quite often fail to meet their minimum standards for quality.

It is difficult, for local suppliers to keep pace with Japanese assemblers and IndoJapanese joint firms that are making what have been described as incremental innovations, or frequent changes in production or process technology originating in Japan. As a consequence, several Japanese automotive MNEs are trying to help local suppliers meet their expectation. For example, Toyota with its jishuken activity has been helping the suppliers for both the automotive and related industry. Toyota Indonesia has been using its jishuken learning group and Toyota way for the Toyota group supplier in tier 1 and tier 2. Consequently, the suppliers who have been trained in Toyota must share the knowledge they learnt for other suppliers in tier 2 and tier 3 who have no direct access to Toyota's jishuken. It is similar in the case of motorcycles, where Honda has been using its learning centre as an incubator for sharing the ideas and difficulty in up-grading motorcycle technology and continuing to use NH circle activity.

Additionally, the Japan Overseas Development Agency and Japan overseas Development Aid has provided training to local managers and technicians for the automotive firms in the Indonesian automotive cluster. They are using matchmaking programmes to promote the transfer of technology and skills. However, such government-supervised matchmaking programmes have failed to bring many Japanese automotive MNEs to sign contracts. That is because they ignore microeconomic reality as Japanese firms do not meet and immediately form links. They just do not operate that way. They require a long drawn out 'romance' before they enter into any kind of relationship. Honda Indonesia has confirmed this argument as follows:

"Managing the managerial responsibilities to non-Japanese companies can take place only gradually, and they required managerial skills and know-how are built through in-house, on-the job-training, and work experience "(Honda representative 29 May 2007)

The automakers are trying to build keiretsu-like supply networks in the Indonesian cluster and Asian clusters to promote technical cooperation and improve the quality of locally produced car. 
"To compete against American and European producers, we need to find the way to reduce costs even further by teaming up with other Japanese 'friends'. Along with that, the purpose to produce joint product is intended to strengthen Japanese market share in Asia" (Toyota representative 8 June 2007)

Therefore, in the quest for efficient supply networks, Japanese automakers in the automotive cluster in Indonesia and Asia are doing something that American manufacturers would never dream of. They are teaming up to form what could be considered super keiretsu. For instance, Toyota and Daihatsu have agreed to use some common components for the family wagon car for Asian market. In addition, Suzuki and Mitsubishi Motors also agreed to produce joint truck programme. Likewise in Thailand, Toyota, Nissan, and Isuzu have begun to collaborate on the production of cylinder blocks for diesel engines. This cooperation was designed partly to satisfy demands for ASEAN market and partly to maintain Japanese domination of the local market.

\section{Making sense of the Global Integrated Production System in the Automotive Industry}

In response to the growth of the car and motorcycle industry in the ASEAN region ${ }^{3}$ and the Asian market, the Indonesian automotive cluster firms increasingly make efforts to improve the production and management systems and contribute to the core global industrial automotive system, not only in manufacturing and sales but also in technology and management. However, the cluster has developed as an extension of the Toyota and Honda keiretsu and so network relations follow a hierarchical structure, with the Japanese firms at the top, followed by the Japanese-owned Indonesian companies, the Indonesian subcontractors within the cluster and those outside it.

This structure has benefited top-down knowledge transfer from Japan into the Indonesian cluster in several ways. First, the keiretsu structure reduced the level of unintended knowledge spillovers outside the cluster. Since the Indonesian firms are encouraged to do business predominantly within their respective keiretsu, the Japanese automotive manufacturers at the top could be confident that their technological and organizational knowledge would be protected. This encouraged topdown knowledge transfer since the Japanese companies would in the end enjoy the benefits themselves. Second, the hierarchical structure proliferated a shared sense of identity and shared purpose, and a shared set of norms, values, and conventions throughout the keiretsu.). These soft factors are important for knowledge transfer, in particular with regard to its tacit dimension (Nonaka et al. 2000, Amin and Cohendet 2004). An effective transfer of tacit knowledge requires a shared frame of reference, a shared social context to interpret and give meaning to knowledge. The keiretsu context has been helpful in this respect.

\footnotetext{
${ }^{3}$ ASEAN region representing approximately 500 million people today in Southeast Asian. ASEAN, a functional integration of a regional community of Southeast Asian states, provides a shared regional identity through its emphasis on ASEAN Way - consensus and mutual consultation.
} 
Nevertheless, it is doubtful whether the vertical network structures will be equally helpful for the Indonesian automotive cluster at the next stage of its development. This would require the Indonesian cluster to start creating knowledge and innovation on its own and consequently engage into horizontal knowledge exchange within the cluster. Horizontal knowledge transfer is essential to make use of the experiences and skills that are present in various companies in the Indonesian cluster and to use them as inputs for the development of new products, services, and processes. Yet, hierarchical organized networks are not a favourable environment for this kind of horizontal communications since it requires the companies at the top of the keiretsu to relinquish some of their control.

The automotive cluster in Indonesia shows that even in a global economy, spatial proximity is still highly relevant, for two reasons. In the first place, the implementation of JIT production systems forge close links between the companies in the cluster. From the perspective of logistics, spatial proximity makes JIT systems more effective and much more cost efficient. Also cooperation between the companies involved may benefit from spatial proximity. Although it is possible to transfer non tacit knowledge over large distances, spatial proximity enhances the 'social depth' of communication (Morgan 1997). Knowledge transfer benefits from a shared social context, a shared set of norms, values, and conventions. Spatially concentrated networks of organizations and people can provide such a context (Morgan 1997). The importance of spatial proximity can be seen in the case of on the job training (OJT) where engineers from the Japanese companies needed to spend time physically in the Indonesian companies to transfer their knowledge and vice versa.

Being part of Toyota and Honda keiretsu has helped the Indonesian companies enormously to upgrade their performance. They developed from work-bench companies doing simple production work to exporting cars and motorcycles globally. This clearly demonstrates the success of the past development trajectory. Yet, as argued, it places the Indonesian companies in a subordinate position to their Japanese patrons. As long as the Indonesian companies cannot stand on their own feet, this is not a bad thing. However, the next step of development requires the Indonesian companies to take matters in their own hands.

In view of their keiretsu philosophy, it is doubtful that either Toyota or Honda will encourage the Indonesian companies in the Indonesian cluster to further upgrade their competencies to become independent automotive companies. Yet, in the long term, this offers the best opportunities for sustained development for the Indonesian companies. In order to achieve that ambition, the Indonesian automotive companies must learn to work together and develop innovative capabilities of their own. To be able to develop new products, services, and processes makes the Indonesian automotive companies more interesting partners not only for their current Japanese partners, but also to other automotive manufacturers.

So far, the efforts of the Indonesian government have been aimed at encouraging the development of the (companies) in the Indonesian automotive cluster as part of the Japanese keiretsu. This strategy was largely born out of necessity because as a developing country, Indonesia did not have the knowledge, skills, and technological capabilities, to upgrade its automotive industry on its own. Even though the catching- 
up process is not finished, the Indonesian government needs to develop a strategy to advance the cluster beyond the catching-up stage. As argued, catching-up can be done largely with the help of the Japanese keiretsu.

The next step requires a much more indigenous effort, and the Indonesian government, therefore, should undertake the following steps to facilitate further development of the (companies) in the Indonesian cluster:

1. Facilitating FDI in the cluster and its companies, for example, through legislation making it attractive for foreign companies to invest in this cluster.

2. Encouraging innovative collaboration between Indonesian and foreign knowledge centres on the one hand and leading companies from the Java cluster on the other hand.

3. Setting up local technological transfer centres with government support to help companies upgrade their performance.

The challenge for the Indonesian automotive cluster now lies in finding new economic development models to propel itself on a trajectory that will enable it to take an independent place in the global automotive industry. This industry can function as an engine, transforming a low wage, labour intensive, and developing economy into a higher-wage, technology-intensive, and developed economy. On the downside, however, the Indonesian automotive clusters have become overly dependent on their Japanese patrons.

In sum, the automotive cluster policy in Java has been successful in forging links between, on the one hand, Japanese automotive makers and local subsidiaries, and on the other hand, between the local subsidiaries and second-tier suppliers located in the automotive cluster. The networks have been helpful for the subsidiary companies to upgrade their performance in several ways: they have received new production technologies from their Japanese patrons, they have improved the skills of their workforce, and they have learned to apply new business concepts, such as quality control and JIT production system. All of this gives the Indonesian automotive cluster a better chance in the global economy.

What the cluster policy so far has failed to recognize are the noticeable risks associated with the heavy dependence on just two Japanese automotive makers. Therefore, the Indonesian government needs to start working on a strategy that will link the automotive clusters in Java to other key automotive firms as well. The newly acquired technologies and skills need to be used as an entry ticket to working with new partners.

\section{References}

ADB. (2006) Indonesia: Country and Strategy Programme. Manila: Asian Development Bank.

Amin, A. (2002) 'Spatialities of globalization ', Environment and Planning, 34, pp. 385-399. 
Amin, A. and Cohendet, P. (2004) Architecture of Knowledge. Firms, Capabilities and Communities. Oxford: Oxford University Press.

Asheim, B. T. and Isaksen, A. (2002) 'Regional Innovation System: The Integration of Local Sticky and Global Ubiquitous Knowledge', Journal of Technology Transfer, 27, pp. 77-86.

Asheim, B. T. and Cooke, P. (1999) 'Local Learning and Interactive Innovation Networks in a Global Economy', in Malecki, E. and Oinas, P.(eds) Making Connections: Technological Learning and Regional Economic Change.Aldershot: Ashgate, pp. 145-178.

Altenburg, T. and Meyer-Stamer, J. (1999) 'How to promote clusters: policy experiences from Latin America ', Word Development, 27.

Aswicahyono, H. and Anas, T. (2000) Understanding the Pattern of Trade in the ASEAN Automotive Industry. Jakarta: CSIS.

Aswicahyono, H., Anas, T. and Rizal, Y. (1999) The Development of the Indonesian Automotive Industry. Jakarta: CSIS.

Bell, M. and Albu, M. (1999) 'Knowledge systems and technological dynamism in industrial clusters in developing countries', World Development, 27, (09).

Bell, M. and Pavitt, K. (1993) 'Technological Accumulation and Industrial Growth: Contrast between Developed and Developing Countries', Industrial and Corporate Change, 2, pp. 157-210.

Biers, D. (1994) "Matshushita Pioneers Effort to Localize", Asian Wall Street Journal, 9 August 1994, p.4.

Boschma, R. and Wenting, R. (2006) The Spatial Evolution of the British Automobile Industry. Utrecht: Utrecht University.

Breziz, E. S. and Krugman, P. (1993) Technology and the life-cycle of cities. CBES

Busser, R. and Sadoi, Y. (2004) 'Introduction', in Sadoi, B. (ed), Production Networks in Asia and Europe: Skill formation and technology transfer in the automobile industry. London: Routledge.

Chia Siow Yue, (1991) "Japanese Overseas Direct Investment in ASEAN and Asian NIES”, a research monograph, VRF Series No. 187, Institute of Developing Economies, Tokyo.

Cantner, U., Dressler, K. and Kruger, J. J. (2004) 'Firm survival in the German automobile industry', Jenaer Schriften zur Wirtschaftswssenschaft, (8/2004), pp. 1-14.

Coe, N., Dicken, P. and Hess, M. (2008) 'Global Production Network: Realizing the Potential', Journal of Economic Geography, 8, pp. 271-295.

Cooke, P. (2001) 'From technopoles to Regional Innovation Systems: The evolution of localised technology development policy', Canadian Journal of Regional Science, XXIV, (1), pp. 21-40.

DeBresson, C. (1996) Economics interdependence and innovative activity: an inputoutput analysis. Cheltenham: Edward Elgar.

Dicken, P. and Henderson, J. (2003) Making the Connections: Global Production Networks in Britain, East asia and Eastern Europe. Final report on ESRC Project R000238535.

Dyer, J. H. and Nobeoka, K. (2000) 'Creating and managing a high-performance knowledge-sharing network: the Toyota case', Strategic Management Journal, 21, pp. 345-367.

Ernst, D. (1994) Carriers of Regionalization: The East Asian Production Networks of Japanese Electronic Firms. 
Ernst, D. and Kim, L. (2002) 'Global Production Network, Knowledge Diffusion, and Local Capability Formation', Research Policy, 31, pp. 1417-1429.

Freeman, C. (1987) Technology Policy and Economic Performance: Lessons from Japan. London: Pinter Publisher.

Fujita, M., Krugman, P. and Venables, A. (1999) The spatial economy: cities, regions, and International trade Cambridge, MA: MIT Press.

Fujita, M. and Krugman, P. (2004) 'The new economic geography: Past. Presence, and the Future', Regional Science, 83, pp. 139-164.

Fujimoto, T. (2007) Competing to be really really good: the behind the scenes drama of capability building competition in the automobile industry. Tokyo: LTCB International Library Trust/International House of Japan.

Gereffi, G. (2001) Beyond the producer-driven/buyer-driven dichotomy. The evolution of Global Value Chains in the Internet Era. IDS Bullettin.

Gereffi, G. (2004) 'The organisation of buyer-driven global commodity chains: how US retailers shape overseas production networks', in Gereffi, G. and Korzeniewicz, M.(eds) Commodity chains and global capitalism. Wesport CT Praeger.

Gereffi, G., Humphrey, J. and Sturgeon, T. (2005) 'The governance of global value chains', RevieW of International Political Economy, 12, pp. 78-104.

Giuliani, E. (2006) 'The selective nature of knowledge networks in clusters: evidence from the wine industry ', Journal of Economic Geography, 7, pp. 139-168.

Harada, T. (2003) 'Three Steps in Knowledge Communication: the emergence of knowledge transformers', Research Policy 32, (1737-1751).

Hanson, G. H. (2001) Should countries promote foreign direct investment?, G-24 Discussion Paper No. 9. New York: United Nations.

Hill, H. (1997) Indonesia's Industrial Transformation. Singapore: Institute of Southeast Asian Studies.

Honda. (2007) Astra Honda Indonesia: Annual Report. Jakarta: Astra Honda Indonesia.

Hatch, W. and Yamamura, K. (1996) Asia in Japan's Embrace: Building a Regional Production Alliance, pp. 108-111. Cambridge: Cambridge University Press.

Humphrey, J. and Schmitz, H. (2000) 'Governance and Upgrading: Linking Industrial Cluster and Global Value Chain Research', IDS Working Paper, 120.

Kiba, T. and Kodama, F. (1991) Measurement and Analysis of the Progress of International Technology Transfer: Case Study of Direct Investment in East Asian Countries by Japanese Companies. Japan: National Institute of Science and Technology Policy, Science, and Technology Agency of Japan.

Klepper, S. (2001) The Evolution of the U.S. Automobile Industry and Detroit as Its Capital. Mimeo: Carnegie Mellon University.

Klepper, S. (2004) Agglomeration through spinoffs: How Detroit became the capital of the US automobile industry. Carnegie Mellon University.

Krugman, P. (1991) 'Increasing returns and economic geography', Journal of Political Economy, 99, pp. 483-499.

Kuncoro, M. (2002) Analisis Spasial dan Regional: Studi Aglomerasi dan Kluster Industri Indonesia. Yogyakarta: UPP AMP YKPN.

Lagendijk, A., D., Charles. (1999) Clustering as a new growth strategy for regional economies? Paris: OECD.

Liu, W. and Dicken, P. (2006) 'Transnational corporations and obligated embeddedness: foreign direct investment in China's automobile industry', Environment and Planning, 38, pp. 1229-1247. 
Lundvall, B. A. (1992) National Innovation Systems: Towards a theory of innovation and interactive learning. London: Pinter Publisher.

Lundvall, B. A. (ed.) (1998) Innovation as an interactive process: from user-producer interaction to the national system of innovation. London: Pinter Publisher.

Meyer-Stamer, J., Maggi, C. and Seibel, S. (2001) Improving upon nature. Creating competitive advantage in ceramic tile clusters in Italy, Spain, and Brazil INEF.

Mikler, J. J. (2007) 'Varieties of capitalism and the auto industry's environmental initiatives: national institutional explanations for firms' motivations', Business and Politics, 9.

Morgan, K. (1997) 'The Learning Region: Institutions, Innovation and Regional renewal', Regional Studies, 31, pp. 491-503.

Morrison, A. and Rabelloti, R. (2005) Inside the black box of industrial atmosphere: Knowledge and information networks in an Italian Wine Local System. Novara: Università del Piomonte Orientale'.

MOSR. (2002) The industrial and research policy in Indonesia. Jakarta: Ministry of Science and Research Republic of Indonesia.

MOTIRI. (2005) The Automotive Industry and its progress. Jakarta: Ministry of Trade and Industry Republic of Indonesia.

Nelson, R. (ed.) (1993) National Innovation Systems: A comparative analysis. Oxford: Oxford University Press.

Narula, R. and Zanfei, A. (2005) 'Globalization of Innovation: The Role of Multinational Enterprises', in Fagerberg, J., Mowery, D. C. and Nelson, R. R. (eds) The Oxford Handbook of Innovation. Oxford: Oxford University, pp. 318-347.

Nonaka, I. and Takeuchi, H. (1995) The Knowledge Creating Company: How Japanese Companies Create the Dynamics of Innovation. Oxford: Oxford University Press.

Nonaka, I., Toyama, R. and Nagata, R. (2000) 'The Firms as the Knowledge-Creating Entity: A new Perspective On The Theory of The Firm', Industrial and Corporate Change, 9, (1-20).

Nooteboom, B. (2004) Intern-firm collaboration, Learning networks: An integrated approach. London: Routledge.

Odaka, K., Ono, K. and Adachi, F. (1988) The Automobile Industry in Japan: A Study of Ancillary Firm Development. Tokyo: Kokusabunken Insatsusha.

Ozawa, T. (2005) Institutions, Industrial Upgrading, and Economic Performance in Japan-The 'Flying-Geese Paradigm of Catch-up Growth. Northampton, Massachusetts: Edward Elgar Publishing.

Patel, P. and Pavitt, K. (eds.) (1998) Uneven (and Divergent) Technological Accumulation among Advanced Countries: Evidence and a Framework of Explanation. Oxford: Oxford University Press.

Pavitt, K. (1987) 'The objectives of technology policy', Science and Public Policy, 14, pp. 182-188.

Pedersen, T., Petersen, B. and Sharma, D. D. (2003) 'Knowledge Transfer Performance of Multinational Companies ', Management International Review, 43, (69-90).

Perdana, A. and Friawan, D. (2007) Economic Crisis, Institutional Changes, and the Effectiveness of Government: The Case of Indonesia Jakarta: CSIS.

Piore, M. J. and Sabel, C. F. (1994) The Second Industrial Divide, Possibilities for Prosperity. New York: Basic Books. 
Pries, L. and Schweer, O. (2004) 'The Product Development Process as a Measuring Tool for Company Internationalization', International Journal of Automotive Technology and Management.

Rasiah, R. (2004) Foreign Firms, Technological Capabilities and Economic Performance: Evidence from Africa, Asia, and Latin America. Cheltenham: Edward Elgar.

Rasiah, R. (2005) 'Foreign Ownership, Technological Intensity and Export Incidence: A study of Auto Parts, Electronics and Garment Firms in Indonesia', International Journal of High Technology and Globalization, 1, pp. 361-380.

Rasiah, R., Sadoi, Y. and Busser, R. (2008) 'Special Issue: Multinationals, Technology and Localization in the Automotive Industry in Asia', Asia Pacific Business review, 14, (1), pp. 1-12.

Sato, Y. (2001) Structure, Features and Determinants of Vertical Inter-firm Linkages in Indonesia. Thesis. University of Indonesia.

Samuels, R (1994) Rich Nation Strong Army: National Security and the Technological Transformation of Japan, Ithaca: Cornell University Press.

Schmitz, H. (1982) 'Growth constraints on small-scale manufacturing in developing countries: a critical review', World Development, 10, (6).

Schmitz, H. (1995) 'Collective Efficiency: growth path for small-scale Industry', Journal of Development Studies, 31, (4).

Schmitz, H. (2000) 'Does Local Co-Operation Matter? Evidence from Industrial Clusters in South Asia and Latin America', Oxford Development Studies, 28, (3), pp. 323-336.

Soesastro, H. (2003) Economic Recovery and Reform in Indonesia. Jakarta: CSIS.

Sugiyama, Y. and Fujimoto, T. (2000) 'Product Development Strategy in Indonesia: A Dynamic View on Global Strategy', in Humphrey, J., Lecler, Y. and Salerno, M. S.(eds) Global Strategies and Local Realities, The Auto Industry in Emerging Markets.New York: Houndsmill, Basington, pp. 176-206.

Tallman, S., Jenkins, M., Henry, N. and Pinch, S. (2004) 'Knowledge, Cluster, and Competitive Advantage', Academy of Management Review, 29, (2), pp. 258271.

Tarmidi, L. T. (2004) 'Indonesian industrial policy in the automobile sector', in Busser, R. and Sadoi, Y.(eds) Production networks in Asia and Europe: skill formation and technology transfer in the automobile industry. London: Routledge, pp. 95-112.

TMI. (2007a) Toyota in Indonesia. Jakarta: Toyota Motor Indonesia

TMI. (2007b) Toyota Indonesia. Available at: http://www.toyota.co.id/company/ (Accessed: May 2009).

Wee, T. K. (2005) Technology and Indonesian's industrial competitiveness. Tokyo: Asian Development Bank.

Yeung, H. W. C. (2000) 'Organising the Firm in industrial Geography I: Networks, Institutions, and Regional Development', Progress in Human Geography, 24, (2), pp. 301-315. 